\title{
OKTATÁS A VÁLTOZÁSBAN, A VÁLTOZÁs OKTATÁSA
}

\author{
TÓTH ALIZ MÁRIA \\ Budapesti Corvinus Egyetem Szociológia és Kommunikációtudomány Doktori Iskola
}

Beérkezett: 2021. január 18., elfogadva: 2021. február 4.

European Journal of Teacher Education, 2020. Volume 43. Issue 4. pp. 453-656. (Special issue: The COVID-19 pandemic and its effects on teacher education). Online ISSN: 1469-5928.

$\mathrm{A} z$ információs és kommunikációs technológiák (IKT) térnyerése jelentős változásokat eredményezett a tudásalapú társadalomban. Az IKT befolyásolja az élet minden területét, átalakította a hétköznapjainkat. Nem kétséges, hogy az oktatás területén is inkrementális jelentősége van. Parra (2012) szerint az iskola az egyik olyan helyszín, amire a technológiának a legnagyobb hatása van, még a tanári szerepet is megváltoztatja.

$\mathrm{Az}$ IKT egy ernyőfogalom, amely magában foglalja a különböző kommunikációs eszközöket és alkalmazásokat, ideértve a rádiót, televíziót, mobiltelefonokat, számítógépet, hálózati hardvert és szoftvert, müholdas rendszereket és az ezen eszközökhöz kapcsolódó különféle szolgáltatásokat és alkalmazásokat, mint például a videokonferencia vagy a távoktatás. Ezeket a technológiákat oktatási célokra is használják, azon belül is a diákok tanulásának, valamint a tanulási környezetnek a támogatására és fejlesztésére (Amutha 2020).

Habár a távoktatás globális terjedését az IKT fejlődése tette lehetővé, mégsem újkeletű a jelenség. A távoktatás gondolata a 19. századig vezethető vissza, igaz, abban az időszakban a tanárok és diákok közti kommunikáció még csupán levelezésen keresztül valósult meg. A ta- nárok a tananyagot levélben küldték ki a diákoknak, akik szintén levélben küldték vissza a megoldott feladatokat. Ez képezte a távoktatás gyökerét. A különböző technológiai újítások (mint például a rádió vagy a televízió) mindig egy-egy új állomást jelentettek a távoktatás fejlesztésében. A nyomtatott anyagokkal együtt mára az audio- és videoanyagok is az oktatás részévé váltak. A távoktatás fejlődésének harmadik szakasza a digitális technológiák megjelenésével jött el, és az internet oktatási környezetként való felhasználásán alapul (Kiryakova 2009).

A COVID-19-pandémia hatására számos oktatási intézmény bezárásra kényszerült, és a tradicionális oktatást felváltotta a vegyes és a távoktatás. Globálisan, a világ minden táján, hirtelen kellett a tanároknak és a diákoknak adaptálódniuk a megváltozott tanítási körülményekhez. Bár a pandémiát megelőző időszak is bővelkedik távoktatással kapcsolatos szakirodalomban, azonban a világjárvány által kiváltott krízis tükrében is fontos megvizsgálni, hogyan alkalmazkodott az elmélet az empíriához. A COVID-19 miatti korlátozások számos kérdést vetettek fel azzal kapcsolatban, hogy miként lehet a tanítást és a tanulást támogatni a tanárképzésben egy olyan időszakban, 
amikor a bizonytalanságban csak egy dolog biztos: a változás.

A European Journal of Teacher Education (EJTE) 43. kötetének 4. száma, amely egy különkiadás is egyben, ezzel az aktuális témával foglalkozik. Az EJTE az Európai Tanárképző Szövetség hivatalos folyóirata. A folyóiratban szereplő cikkek olyan, oktatással kapcsolatos kutatásokkal foglalkoznak, amelyek elsősorban a tanárképzés elméletét, politikáját és gyakorlatát vizsgálják Európa országaiban. ${ }^{1} \mathrm{~A}$ 2020-as különkiadás a téma globális érintettsége miatt a világ számos országából származó kutatók tanulmányait gyüjtötte össze - Európa határain túlmutató lokális problémákat is bemutatva.

Érdemes megemlíteni, hogy tanárképzéssel kapcsolatos kutatásokat közlő egyéb folyóiratok is kiadtak különszámot a COVID-19-re adott válaszreakcióként. Az International Dialogues on Education: Past and Present (IDE-Online Journal) online folyóirat 7. kötete 15 tanulmányt szentelt a pandémia hatására kialakuló oktatási helyzet elemzésére. ${ }^{2} \mathrm{~A}$ Electronic Journal for Research in Science E Mathematics Education 24. kötetének októberben megjelent 3. száma a járvány természettudományos tanárképzésre gyakorolt hatásával foglalkozik. A Journal of Education for Teaching 46. kötetének 3. száma 2020 júniusában jelent meg, és arra keresi a választ, hogy a tanárképzés hogyan reagál hosszabb távon a COVID-19 kihívásaira.

A jelen ismertetőben bemutatott lapszám 2020 szeptemberében jelent meg. Tehát már az első hullám utáni időszak tapasztalatait tudta összegezni. A kiadvány egy bevezetőből és 12 nemzetközi tanulmányból áll. A tanulmányok különböző kontextusokba helyezve reflektálnak

https://atee.education/knowledge-center/ejte/

2 Lásd Harsányi Péter recenzióját a rovatban! a járvány következményeire, és azt kutatják, hogy a COVID-19-járvány milyen módon befolyásolta a tanárképzést, a tanárképzésben részt vevő diákok és a kezdő tanárok munkáját.

Akik már oktattak online, tudják, hogy a színvonalas online oktatás sokszor nehezebb és több felkészülést igényel, mint a személyes jelenlétet igénylő, klasszikus tantermi megfelelője. A távoktatás nem új keletű fogalom, azonban az online oktatás mindössze pár évtizedes gyakorlattal bír. Ennek ellenére igen gazdag empíriával és szakirodalommal rendelkezik, tehát feltételezhetnénk, hogy az online oktatásra való átállásra már létezett bevált forgatókönyv - a COVID-19-pandémia kiváltotta kényszerhelyzet elött is. A folyóiratban szereplő tanulmányok azonban arra világítanak rá, hogy kitaposatlan úton jártak azok az oktatók és diákok, akik egyik napról a másikra a tanteremből kiszakítva a személytelen digitális oktatási térbe kényszerültek.

A folyóirat második tanulmányában (COVID-19 and teacher education: a literature review of online teaching and learning practices), a szerzők - Carmen Carrillo Aguilera és Maria Assunção Flores - összesen 134 online oktatásról és oktatási gyakorlatról szóló empirikus tanulmányt elemeztek. Azt találták, hogy a sikeres online oktatáshoz elengedhetetlen, hogy a tanulók és a tanárok egymással interakcióba tudjanak lépni, együtt tudjanak müködni. A szociális kapcsolatok ápolásának lehetősége nagyban befolyásolja a tanuló közösségek összetartását is. A kötet kilencedik tanulmánya (Online teaching placement during the COVID-19 pandemic in Chile: Challenges and opportunities) esettanulmányokon keresztül mutatja be, hogy melyek a virtuális oktatás kihívásai és lehetőségei. A szerzők, Paulina SepulvedaEscobar és Astrid Morrison eredményei 
azt mutatják, hogy a diákokkal való közvetlen interakció hiánya és a hirtelen történt környezetváltozás voltak azok a tényezők, amelyek leginkább negatívan érintették a kutatásban részt vevő válaszadókat.

$\mathrm{A} z$ online oktatás során a tanároknak arra kell törekedniük, hogy az online órákba minél több olyan feladatot beépítsenek, amelyek aktív részvételre, konstruktív párbeszédre sarkallják a diákokat. Pedagógiai szempontból kiemelten fontos a technológia integrálása az online oktatás tanmenetébe. Figyelembe kell venni az online eszközökhöz kapcsolódó pedagógiai lehetőségeket, fel kell tárni, melyek azok az eszközök, amelyek segíthetik a diákok közötti kollaborációt. Például az online fórumok lehetővé teszik a különböző észrevételek megosztását; a chatszobák támogathatják a csoport tagjai közötti kommunikációt és együttműködését; a videós anyagok pedig segíthetnek az elméletet a gyakorlatban is bemutatni. A szociális kapcsolatok ápolása az online térben mindenki számára kihívást jelent. Nem véletlen, hogy a folyóirat több tanulmánya is arra a kérdésre keresi a választ, hogy miként lehet a távoktatásban is fenntartani a jó tanár-diák kapcsolatot.

A folyóirat első tanulmányában (Preparing educators for the time of COVID ... and beyond) a szerzők - Linda DarlingHammond és Maria E. Hyler - arra hívják fel a figyelmet, hogy nemcsak a tanároktól követel újfajta gondolkodásmódot a távoktatás, hanem a döntéshozóktól is; intézményi szinten kell támogatni a dolgozók mentorálását és együttműködését annak érdekében, hogy létrejöhessen az a kollektív tudás, amely a krízis utáni időszakban is kellő mankóként szolgálhat az online oktatás útján.

A tanulmányokat olvasva felvetődhet az olvasóban az a kérdés, hogy jelenleg a világ különböző tájain mennyire állnak készen a tanárok az online oktatásra. $\mathrm{A} z$ EJTE különkiadásában erre is megpróbál választ adni. A Ramona Maile Cutri, Juanjo Mena és Erin Feinauer Whiting szerzőkhöz köthető ötödik tanulmány (Faculty readiness for online crisis teaching: Transitioning to online teaching during the COVID-19 pandemic) vegyes vizsgálati módszereket alkalmazva mérte fel a tanári kar online felkészültségét. A szerzők az oktatói felkészültség szempontjait a meglévő szakirodalom alapján határozták meg. A kutatás válaszadói az online oktatás olyan kihívásaira hívták fel a figyelmet, mint a hibázástól és kockázatvállalástól való félelem. A válaszokból az is kiderült, hogy ez a fajta sebezhetőség előmozdította az empátia, alázatosság, sőt az optimizmus érzését is az oktatókban.

A kötet hetedik tanulmánya (Come to a screeching halt': Can change in teacher education during the COVID-19 pandemic be seen as innovation?) a hatodik cikkhez hasonló kérdésköröket boncolgat. A tanulmány szerzői (Viv Ellis, Sarah Steadman és Qiming Mao) tanárképzések (initial teacher education) vezetőivel készítettek interjút. Míg a hatodik fejezetben (Warren Kidd és Jean Murray írásában) bemutatott kutatás hasonló módszertanra épült, de a kiválasztott minta angliai oktatókra volt szűkítve, addig jelen tanulmány szerzői a világ négy régiójának (Ázsia, Európa, Észak-Amerika és Óceánia) egyetemein vezető pozíciót betöltő szakemberekkel készítettek félig strukturált interjúkat. A két kutatás - a vizsgált minták lokális-globális különbségének ellenére - hasonló konklúzióval zárul: jóllehet, a tanárok nem kaptak elégséges felkészítést az online oktatásra, a COVID-19 következtében kialakult krízishelyzet egy olyan innovatív hozzáállást eredményezett, amely gyakran hiányzik ebből a szektorból. 
A nyolcadik tanulmány (Rethinking teacher education in a VUCA world: Student teachers' social-emotional competencies during the Covid-19 crisis) azokkal a szociális kompetenciákkal foglalkozik, amelyek ahhoz szükségesek, hogy a diákok megbirkózhassanak a COVID-19 teremtette szélsőséges helyzettel. A szerzők kvalitatív kutatása arra kereste a választ, hogy a tanárképző oktatási anyag vajon elegendő szociális és érzelmi kompetenciával vértezi-e fel a hallgatókat a pandémia által kiváltott oktatási krízishelyzet kezelésére. A kutatás eredményei azt mutatják, hogy a tanárképzésben részt vevő hallgatók nem kapnak elégséges felkészítést azokra a kompetenciákra, amelyek szükségesek lennének a jelenlegi helyzetben.

A tizedik tanulmány (Adapting to online teaching during COVID-19 school closure: Teacher education and teacher competence effects among early career teachers in Germany), arról számol be, hogy miként alkalmazkodtak a pályakezdő tanárok az online oktatáshoz, miután az iskolák bezárásra kényszerültek Németországban. A szerzők (Johannes König, Daniela J. Jäger-Biela és Nina Glutsch) 2020 májusa és júniusa között készítettek felmérést pályakezdő tanárokkal. Arra az eredményre jutottak, hogy a tanárok képesek voltak fenntartani a kapcsolatot a diákokkal és a szülőkkel, illetve többségük arról számolt be, hogy a feladatok kiosztása és a megoldásokra adott visszajelzések mellett új tananyagokat is át tudtak venni. Bizonyos információs és kommunikációs technológiák (pl. online oktatás, online értékelés) elsajátításában, alkalmazásában már kevésbé voltak sikeresek. A tanulmány konklúziója az, hogy az IKT-eszközei, különösen a digitális tanári kompetencia, illetve a digitális kompetenciák elsajátításához szükséges tanárképzési lehetőségek fontos szerepet játszanak a COVID-19 miatti iskolabezárásokhoz való alkalmazkodásban.

A kötet tanulmányai részletesen bemutatják a távoktatás, azon belül is az online oktatás szakirodalmának alkalmazhatóságát a gyakorlatban, rávilágítanak az online oktatás szociális, kognitív és érzelmi kihívásaira, valamint bemutatják azt is, hogy milyen felkészültségi szinten állnak a tanárok a világ különböző pontjain. A befejező tanulmányok kitekintésként is szolgálnak a pandémia krízise utáni időszakra.

A tizenegyedik tanulmány (Teachers' online teaching expectations and experiences during the Covid-19-pandemic in the Netherlands) szerzői által készített felmérés rávilágít arra, hogy a tanárok innovációra való hajlandósága nőtt az online oktatásra való áttérés nyomán, és többségük azt tervezi, hogy a koronavírus után is használni fogja a technológiát az oktatásban. A szerzők szerint az elkövetkezendő kutatásoknak arra kellene fókuszálniuk, miként lehetne megalkotni és tesztelni olyan oktatási terveket, amelyek azt segítik elö, hogy a tanárok minél professzionálisabban sajátíthassák el a technológia használatát a mindennapi oktatási gyakorlatban.

Végül a kötet befejező írása (Novice teachers in a changing reality) a pályakezdő tanárok tapasztalatait mutatja be a COVID-19 buborékában. A tanulmány segít megérteni a kezdő tanárok tapasztalatait a válság bizonytalan és zűrzavaros időszakában, valamint rávilágít azokra a szakmai dilemmákra és feszültségekre, amelyek a pályakezdő tanárok szakmai identitásának építését kísérték.

A folyóirat több szinten is rendkívül kiegyensúlyozott: a kötetben szereplő tanulmányok szerzői különböző nemzetiségűek, és a felvonultatott problémák és kihívások is többféle országra és régióra vetítve kerülnek bemutatásra. Szintén ki- 
egyensúlyozott a folyóirat a kritikai hangvétel tekintetében is: vannak tanulmányok, amelyek kritizálják a jelenlegi állapotokat, mások az oktatók agilitását dicsérik, és optimistán szemlélik a jövőt. Bár elsőre azt gondolhatnánk, hogy a tanárképzésből kikerülő matematikatanároknak más kihívásokkal kell számolniuk, mint a testneveléstanároknak, a tanulmányokból kiderül, hogy ez nem így van: a nehézségek nagyrészt azonosak voltak.

$\mathrm{A} z$ EJTE különszáma nem tekinthető egyedülálló vállalkozásnak, hiszen számos egyéb szakmai folyóirat is nagyjából azonos időpontban jelentkezett ugyanezzel a témával. Mindez azonban egyáltalán nem csökkenti jelen tanulmánygyüjtemény jelentőségét. A COVID-19-járvány ugyanis drámaian megváltoztatta az emberek mindennapi életét, és eddig soha nem tapasztalt kihívások elé állította a tanárképzést is. Hatását valószínúleg még évtizedekig érezni fogjuk, épp ezért ezek az első tanulmányok és tapasztalatok egyfajta alapot jelenthetnek, amire az elkövetkezendő kutatások eredményesen építhetnek.

\section{IRODALOM}

Aмuтна, D. (2020) The Role and Impact of ICT in Improving the Quality of Education. http://dx.doi.org/10.2139/ssrn.3585228

Kiryakova, G. (2009) Review of Distance Education. Trakia Journal of Sciences, Vol. 7. No. 3. pp. 29-34. ISSN 1313-3551 (online)

Parra, C. (2012) TIC, conocimiento, educación y competencias tecnológicas en la formación de maestros. Nómadas, No. 36. pp. 145-159. ISSN: 0121-7550

A cikk a Creative Commons Attribution 4.0 International License (https://creativecommons.org/licenses/ by-nc/4.0/) feltételei szerint publikált Open Access közlemény, melynek szellemében a cikk bármilyen médiumban szabadon felhasználható, megosztható és újraközölhető, feltéve, hogy az eredeti szerző és a közlés helye, illetve a CC License linkje és az esetlegesen végrehajtott módosítások feltüntetésre kerülnek. 